\title{
Morphogenetic characteristics and management of Tanzania grass ${ }^{(1)}$
}

\author{
Patricia Menezes Santos ${ }^{(2)}$, Marco Antônio Alvares Balsalobre ${ }^{(3)}$ and Moacyr Corsi( ${ }^{(3)}$
}

\begin{abstract}
The objective of this work was to evaluate the effect of grazing interval and period of evaluation over tissue turnover in Tanzania grass pastures (Panicum maximum cv. Tanzania) and to ascertain if herbage accumulation rate can be used as a criterion to establish a defoliation schedule for this grass in Southeast of Brazil. A randomized block design with a split-plot arrangement was used. The effect of three grazing intervals was evaluated within seven periods between October 1995 and September 1996. Responses monitored were leaf and stem elongation rates, leaf senescence rate, stem length, and tiller density. Net herbage accumulation rate was calculated using tissue turnover data. The grazing intervals for Tanzania grass should be around 38 days between October and April (spring and early autumn) and 28 days during the reproductive phase of the grass (April/May). Between May and September (late autumn and winter), grazing interval should be around 48 days. Herbage accumulation rate is not a good criterion to establish defoliation time for Tanzania grass. Studies on the effects of stem production in grazing efficiency, animal intake and forage quality are needed to improve Tanzania grass management.
\end{abstract}

Index terms: leaves, elongation, senescence, grazing systems.

\section{Características morfogenéticas e manejo de capim-tanzânia}

Resumo - O objetivo deste trabalho foi avaliar o efeito do intervalo entre pastejos e do período de avaliação sobre algumas características morfogenéticas do capim-tanzânia (Panicum maximum cv. Tanzânia) e verificar se o manejo desse capim pode ser baseado na taxa de acúmulo de matéria seca na região Sudeste do Brasil. Foi utilizado um delineamento de blocos completos ao acaso com parcelas subdivididas no tempo. Foi avaliado o efeito de três intervalos entre pastejos e de sete períodos de avaliação entre outubro de 1995 e setembro de 1996 sobre: taxa de alongamento foliar e dos colmos, taxa de senescência foliar, altura dos colmos e densidade populacional de perfilhos. Essas informações permitiram determinar a taxa líquida de acúmulo de matéria seca. O capim-tanzânia deve ser pastejado com cerca de 38 dias no período de outubro a abril, com 28 dias na fase reprodutiva (abril/maio) e com aproximadamente 48 dias entre maio e setembro. O intervalo entre pastejos do capim-tanzânia não deve ser estabelecido apenas com base na taxa de acúmulo de matéria seca. São necessários estudos sobre as interações entre produção de hastes e eficiência de pastejo, consumo e qualidade de forragem, a fim de se determinar melhor o manejo desse capim.

Termos para indexação: folha, alongamento, senescência, sistema de pastejo.

\footnotetext{
(1) Accepted for publication on May 6, 2003.

${ }^{(2)}$ Embrapa-Centro de Pesquisa de Pecuária do Sudeste, Caixa Postal 339, CEP 13560-970 São Carlos, SP. E-mail: patricia@cppse.embrapa.br

${ }^{(3)}$ Escola Superior de Agricultura Luiz de Queiroz, Dep. de Zootecnia, Av. Pádua Dias 11, CEP 13400-000 Piracicaba, SP. E-mail: maabalsa@linkway.com.br, moa@esalq.usp.br
}

\section{Introduction}

Tanzania grass is a tropical bunch-type grass used for grazing in Brazil. It was selected among Panicum maximum genotypes because of its high herbage production (33 t/ha/year of total herbage dry matter and $26 \mathrm{t} / \mathrm{ha} /$ year of leaf herbage dry matter) 
and good forage quality $(12.7 \%$ crude protein in leaves and $9 \%$ crude protein in stems) (Jank et al., 1994). In spite of that, animal production in Tanzania grass areas is not consistent. Stocking rates in Tanzania grass experimental areas vary from two to nine animal unit/ha (Côrrea, 2000; Penati, 2002; Quadros et al., 2002) and animal gains vary from 0.145 to $0.850 \mathrm{~kg} /$ animal/day (Euclides et al., 1999; Côrrea, 2000). Many factors may contribute to these differences, like seasonal forage production (Santos et al., 1999), soil fertility and grazing efficiency (Quadros et al., 2002).

Experimental results have shown the importance of maximizing grazing efficiency to obtain the best return from pastures (Hodgson, 1990). For rotationally grazed swards, it has been considered that, to attain the best balance between photosynthesis, production and senescence, swards should be harvested during the phase of maximum average growth rate. However, in situations of high growth rate, management should concentrate on the control of stem development (Parsons \& Penning, 1988).

There is little information about the effects of plant morphology on grazing behaviour for tropical grasses, but there is no doubt about the negative effect of stems on grazing efficiency and forage intake. Sollenberger \& Burns (2001) have suggested bite weight to be a function of leaf percentage, leaf mass and green herbage mass of the upper strata of the canopy. Besides that, the manner in which leaf is presented to the animal and the degree to which it can be apprehended separately from stems and dead material of low digestibility have a great influence in tropical pastures (Euclides et al., 1999; Sollenberger \& Burns, 2001).

Tissue turnover in pastures may be measured using estimates of tissue synthesis and death rates associated with tiller population density. Calculation of tissue synthesis rate may be based on leaf growth only or on leaf and stem growth. For tropical bunch-type grasses, stems may represent more than $50 \%$ of herbage production (Andrade, 1987). In this case, it is important to evaluate stem growth rate because it interferes with animal intake and grazing behaviour (Flores et al., 1993).

The objective of this work was to evaluate some morphogenetic characteristics in Tanzania grass and to ascertain if herbage accumulation rate can be used as a criterion to establish a defoliation schedule for this grass.

\section{Material and Methods}

The experiment was carried out in Piracicaba, SP, Brazil (22042'30" S and 47³8'30" W), between October 1995 and September 1996 in an one-year-old Tanzania grass pasture. The soil was classified as an Alfisol $\left(\mathrm{pH} \mathrm{CaCl}_{2}, 5,9\right.$; organic matter, $26,5 \mathrm{~g} / \mathrm{dm}^{3} ; \mathrm{P}$, $60,5 \mathrm{mg} / \mathrm{dm}^{3} ; \mathrm{S}, 40,9 \mathrm{mg} / \mathrm{dm}^{3} ; \mathrm{K}, 8,5 \mathrm{mmol}_{\mathrm{c}} / \mathrm{dm}^{3} ; \mathrm{Ca}$, $70,5 \mathrm{mmol}_{\mathrm{c}} / \mathrm{dm}^{3} ; \mathrm{Mg}, 28,0 \mathrm{mmol}_{\mathrm{c}} / \mathrm{dm}^{3} ; \mathrm{H}+\mathrm{Al}$, $\left.20,0 \mathrm{mmol}_{\mathrm{c}} / \mathrm{dm}^{3} ; \mathrm{Al}, 0 \mathrm{mmol}_{\mathrm{c}} / \mathrm{dm}^{3}\right)$. A randomized block design with a split-plot arrangement was used, involving three grazing intervals ( 28,38 and 48 days) as the main plots and seven evaluation periods (October/December, January/ February, February/April, April/May, May/July, July/August, and August/September) as subplots, with seven replicates of $10 \mathrm{~m} \times 13 \mathrm{~m}$ plots. Temperature and rainfall data over the duration of the study are presented in Figure 1.

All plots were harvested in October 1995 and thereafter they were grazed by Holstein cows and heifers each 28, 38 or 48 days, according to the treatment. Average post grazing herbage mass was $1,900 \mathrm{~kg} / \mathrm{ha}$. In each plot $400 \mathrm{~kg} / \mathrm{ha}$ of $\mathrm{N}$ were applied as urea during the summer in 6, 5 and 4 applications for the 28, 38 and 48-day-grazing-intervals, respectively.

A transect was marked in each plot and ten tillers were marked at their base using coloured wire rings. Before grazing, the green length of individual lamina (from the ligule to the tip or to the beginning of the green part) and stem (from soil to the youngest ligule) were recorded three times, once each two (between October and early May) or three days (between late May and September). In the case of immature laminae, length noted was from the leaf tip to

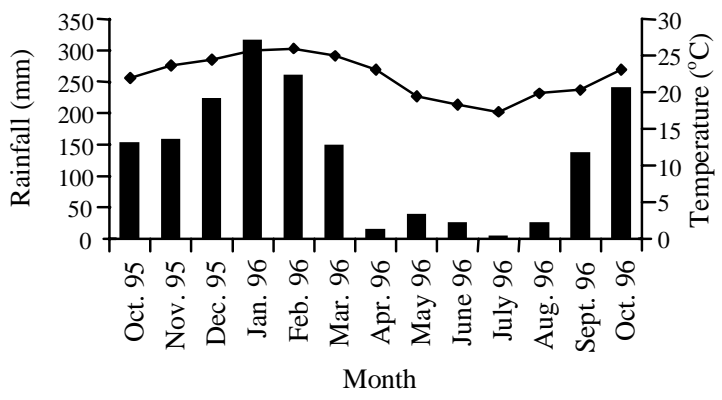

Figure 1. Rainfall ( $\square$ ) and temperature $(\diamond)$ data between October 1995 and October 1996. 
the ligule of the previous one. Leaf elongation rate ( $\mathrm{cm} /$ tiller/day) was determined by the difference between final and initial length of expanding leaves divided by the number of days between measurements; stem elongation rate $(\mathrm{cm} /$ tiller/day) was measured by the difference between initial and final stem length divided by the number of days between measurements; senescence rate ( $\mathrm{cm} /$ tiller/day) was obtained by the difference between final and initial length of senescent leaves divided by the number of days between measurements; stem length $(\mathrm{cm})$ was determined by the average of the three stem length measurements made before each grazing and tiller population density (tiller $/ \mathrm{m}^{2}$ ) was recorded by counting tiller numbers on four $0.5 \mathrm{~m}$ x $1.0 \mathrm{~m}$ samples per plot.

One day before grazing, tillers used to evaluate leaf and stem elongation rate and leaf senescence rate were collected and the correlation between length and dry weight of stems, expanding leaves and mature leaves was established. This data, combined with tissue turnover and tiller population density, allowed the elaboration of herbage accumulation curves for Tanzania grass during the year (Grant et al., 1983; King et al., 1984).

Analysis of variance (ANOVA) was conducted using the SAS GLM procedure (SAS Institute, 1986) and means were compared using the LSD test $(\mathrm{P}<0.05)$. Data were transformed when it showed variance heterogeneity. Leaf elongation rate, senescence rate and tiller population density were transformed using the function square root, stem elongation rate was transformed using the function $\log _{10}$, and stem length was transformed using the function $\log _{\mathrm{n}}$. As the transformation did not affect the interpretation of the results, back transformed data are presented for clarity.

\section{Results and Discussion}

There was no effect of grazing intervals on leaf elongation rate in January/February (Table 1). In October/December, May/July and August/September, leaf elongation rate increased when grazing intervals increased and in February/April and April/May, it decreased when grazing intervals increased. Leaf elongation rates observed by Barbosa et al. (2002) for new (1.87 cm/tiller/day) and old tillers $(2.01 \mathrm{~cm} /$ tiller/day) during October/December were lower than that observed in the present work. In July/August, it was lower with 38 days compared to 48-day-grazing-interval, but the 28-day-treatment showed no difference. In April/May, almost all tillers of the 48 days of grazing interval treatment had flowered and leaf production had stopped. In this case, data were not considered for statistical analysis to allow model adjustment.

Stem elongation rate was higher with a 48-day-grazing-interval than with either 28 or 38-day-grazing-interval in October/December, January/February and May/July. In February/April, April/ May and July/August, grazing intervals had no effect on stem elongation rate while in August/September, stem elongation rate was lowest with 28-day-interval.

The highest leaf and stem elongation rates were obtained during high temperature and rainfall (Table 1 and Figure 1). Temperature may be one of the most important variables affecting leaf elongation rate (Baker \& Younger, 1987), which reflects on herbage production. Leaf appearance, stem elon-

Table 1. Effects of grazing intervals and period of evaluation on leaf and stem elongation rate ( $\mathrm{cm} / \mathrm{tiller} /$ day) in Tanzania $\operatorname{grass}^{(1)}$.

\begin{tabular}{|c|c|c|c|c|c|c|c|}
\hline \multirow{2}{*}{$\begin{array}{c}\text { Grazing } \\
\text { intervals (days) }\end{array}$} & \multicolumn{7}{|c|}{ Evaluation period } \\
\hline & $\begin{array}{l}\text { October/ } \\
\text { December }\end{array}$ & $\begin{array}{l}\text { January/ } \\
\text { February }\end{array}$ & $\begin{array}{c}\text { February/ } \\
\text { April }\end{array}$ & $\begin{array}{l}\text { April/ } \\
\text { May }\end{array}$ & $\begin{array}{l}\text { May/ } \\
\text { July }\end{array}$ & $\begin{array}{c}\text { July/ } \\
\text { August }\end{array}$ & $\begin{array}{c}\text { August/ } \\
\text { September }\end{array}$ \\
\hline & \multicolumn{7}{|c|}{ Leaf elongation rate } \\
\hline 28 & $5.83 \mathrm{Bb}$ & $7.27 \mathrm{Aa}$ & $7.75 \mathrm{Aa}$ & $3.86 \mathrm{Ac}$ & $1.96 \mathrm{Bd}$ & $1.24 \mathrm{ABe}$ & $2.29 \mathrm{Cd}$ \\
\hline 38 & $6.53 \mathrm{Bb}$ & $7.45 \mathrm{Aa}$ & 7.47ABa & $3.21 \mathrm{Bd}$ & $2.05 \mathrm{Be}$ & $1.06 \mathrm{Bf}$ & $3.05 \mathrm{Bc}$ \\
\hline 48 & $9.94 \mathrm{Aa}$ & $7.42 \mathrm{Ab}$ & $6.70 \mathrm{Bb}$ & - & 2.66Ad & $1.46 \mathrm{Ae}$ & $3.76 \mathrm{Ac}$ \\
\hline & \multicolumn{7}{|c|}{ Stem elongation rate } \\
\hline 28 & $0.46 \mathrm{Bd}$ & $0.70 \mathrm{Bc}$ & $1.04 \mathrm{Ab}$ & $1.58 \mathrm{Aa}$ & $0.10 \mathrm{Be}$ & $0.10 \mathrm{Ae}$ & $0.14 \mathrm{Be}$ \\
\hline 38 & $0.61 \mathrm{Bb}$ & $0.85 \mathrm{Bb}$ & $0.87 \mathrm{Ab}$ & $2.16 \mathrm{Aa}$ & $0.08 \mathrm{Bd}$ & $0.10 \mathrm{Ad}$ & $0.29 \mathrm{Ac}$ \\
\hline 48 & $1.02 \mathrm{Ab}$ & $1.81 \mathrm{Aa}$ & $1.21 \mathrm{Ab}$ & $1.92 \mathrm{Aa}$ & $0.19 \mathrm{Ad}$ & $0.08 \mathrm{Ae}$ & $0.35 \mathrm{Ac}$ \\
\hline
\end{tabular}

${ }^{(1)}$ Means followed by the same lower case letter in a row or the same upper case letter in a column do not differ significantly by the LSD test $(\mathrm{P}<0.05)$; pasture was grazed by Holstein cows and heifers. 
gation and tillering rates and total dry matter yield in Elephant grass were higher at day/night temperatures of $30 / 25^{\circ} \mathrm{C}$ than of $21 / 16^{\circ} \mathrm{C}$ (Ferraris, 1978).

There was no interaction between grazing intervals and period of evaluation for leaf senescence rate and therefore just the main effects were analyzed. Leaf senescence rate increased as grazing interval increased $(0.34,0.71$, and $2.01 \mathrm{~cm} /$ tiller/day for 28, 38 and 48-day-grazing-intervals treatments, respectively). Barbosa et al. (2002) observed a leaf senescence rate around $1.3 \mathrm{~cm} /$ tiller/day on Tanzania grass in November.

Rates of leaf senescence from May until September were almost null, and thus these data were not considered for statistical analysis. Leaf senescence rate was higher during January/February $(1.13 \mathrm{~cm} / \mathrm{til}$ ler/day) and February/April (1.05 cm/tiller/day) than during October/December $(0.52 \mathrm{~cm} /$ tiller/day) and April/May ( $0.64 \mathrm{~cm} /$ tiller/day). The low rates of leaf senescence observed in April/May may be attributed to the high proportion of reproductive tillers. During the reproductive phase, light distribution can be better due to stem elongation thus better luminosity inside plant canopy may reduce the leaf senescence rate (Woledge, 1972; Noodën et al., 1996). On the other hand, senescence is developmentally regulated and hormonally controlled (Hopkins, 1995), and therefore hormonal changes caused by floral initiation are likely to modify senescence rate too.

Only the period of evaluation affected tiller population density; there was no effect of grazing intervals, as referred. The highest tiller population density was observed in October/December (359 tillers $/ \mathrm{m}^{2}$ ) and the lowest in April/May (136 tillers $/ \mathrm{m}^{2}$ ). Along the rest of the year, it remained almost constant (around 206 tillers $/ \mathrm{m}^{2}$ ). The low tiller population density in April/May may be justified by the increase on tiller weight and the competition between tillers due to flowering (Hodgson, 1990).

Costa et al. (1992) observed that tiller population density on Panicum maximum cvs. Tobiatã and Colonião was lower when plants were cut every 42 days compared to 28 and 35 days. Santos (1997) observed no effect of grazing interval on tiller population density of Panicum maximum cv. Mombaça. The inconsistent effect of defoliation interval on tiller population density of Panicum maximum may be due to defoliation level, season, plant developmental phase or cultivar differences.

Since there was no effect of grazing intervals on tiller population density, net herbage accumulation and senescence rates reflected the variations on leaf and stem elongation and leaf senescence rates (Figure 2).

In October/April, senescence rate of Tanzania grass increased as grazing intervals increased, espe-
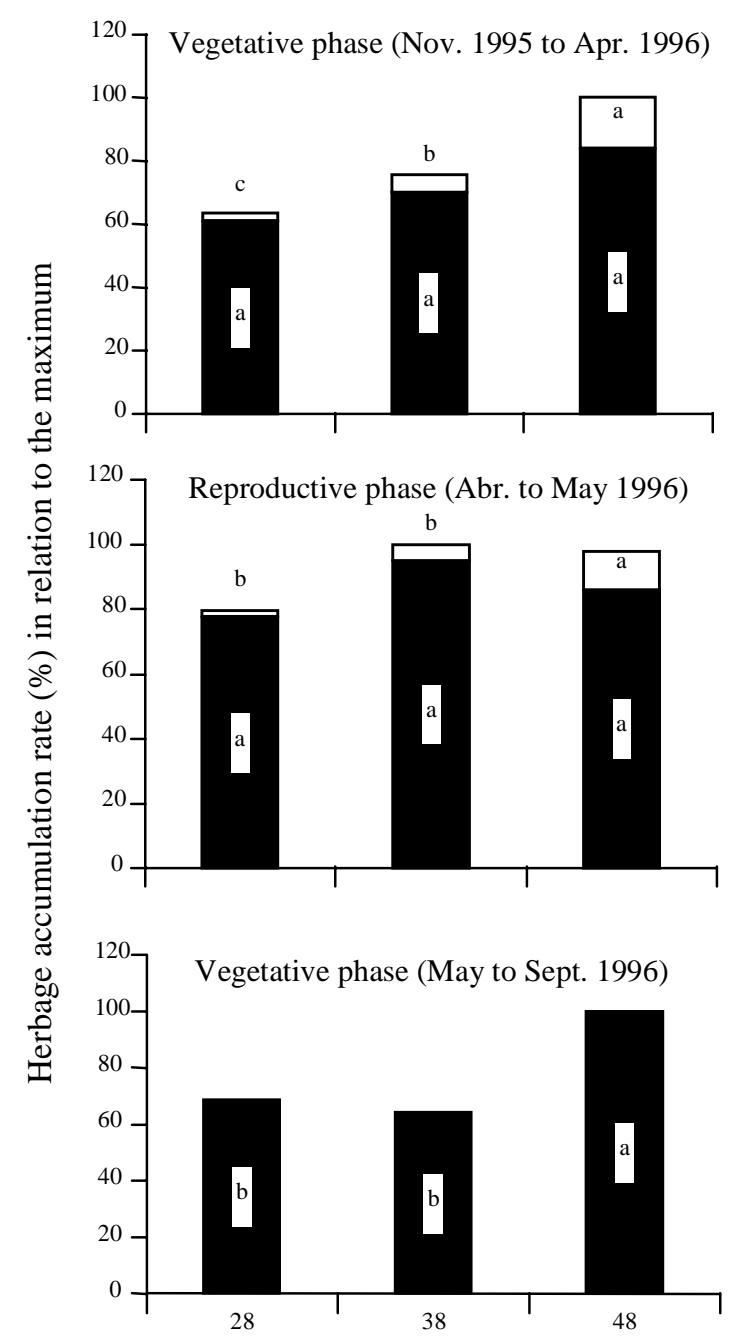

Grazing interval (days)

Figure 2. Net herbage accumulation $(\mathbf{\square})$ and senescence $(\square)$ rate of Tanzania grass in the vegetative and reproductive phases. Means in each phase followed by the same letter do not differ significantly by the LSD test $(\mathrm{P}<0.05)$. 
cially from 38 to 48 days. Despite that, grazing interval had no effect on net herbage accumulation rate (Figure 2). These data suggest that at 48 days of grazing intervals, production will not be reduced, but grazing efficiency may be higher if a 38-dayrest-period be adopted. Because of that, it was proposed a 38-day-grazing-interval for Tanzania grass between October and April.

During the reproductive phase (April/May), net herbage accumulation rate was not affected by grazing intervals, but senescence rate increased as grazing intervals increased from 38 to 48 days (Figure 2).

Herbage accumulation during the reproductive (April/May) period reflected mostly stem growth (leaf elongation rate in April/May reduced as grazing intervals increased and were null on the 48-day-treatment due to flowering) (Table 1). Besides that, stem length increased as grazing intervals increased (except during July/August when no grazing interval effect was observed) and, for all grazing intervals, the highest stem length was observed in April/May, during the reproductive phase (Table 2). For temperate grasses, it has been observed that stem length limits bite depth (Barthram \& Grant, 1984; Flores et al., 1993). For tropical grasses, there is almost no information about the influence of stems on animal grazing behaviour. However, Euclides et al. (1999) observed that forage intake, grazing time and animals performance were more related to pasture morphological characteristics (leaf mass and proportion of green and dead herbage mass) than to forage nutritive value in Tanzania grass pastures.

Stem nutritive value decreases faster than the leaves nutritive value as grass ages (Andrade, 1987; Singh, 1995). In addition to that, the lower retention time of leaves allows a higher intake than that of stems, even when digestibility, neutral and acid detergent fibers and lignin were similar (Poppi et al., 1981; Forbes \& Coleman, 1993).

Leaf:stem ratio data of the present work was published previously (Santos et al., 1999). It was highest in October/December, but never exceeded 1.89. From January to March, stems proportion increased and the leaf:stem ratio was between 1.02 and 1.17 (except for 28-day-grazing-interval, where the leaf:stem ratio was 1.42). During April/May, leaf:stem ratio was 1.0 or less. The low leaf:stem ratios observed for Tanzania grass during the present work suggest that this feature should be considered to establish the best rest period for this grass and that, in some seasons, it may be more important to control stem production than to maximize net herbage accumulation rate or to reduce losses due to senescence.

It is concluded that studies are necessary to investigate the effect of leaf:stem ratio on forage quality and intake. It is not an easy task, because the influence of leaf:stem ratio on animal performance will depend on grazing pressure and on post graze herbage mass. However, it is already possible to confirm that, during the reproductive phase, grazing intervals of Tanzania grass should be less than 28 days, regardless of its net herbage accumulation rate.

From May until September, net herbage accumulation rate increased as grazing intervals increased and there was almost no senescence (Figure 2). Hence, grazing intervals during this period should be higher than 48 days.

The equilibrium between tissue production and senescence was never attained along the year. This allows a certain flexibility for Tanzania grass management because it means that even with very high grazing intervals, a net herbage accumulation will

Table 2. Effects of grazing intervals and period of evaluation on stem length $(\mathrm{cm})$ of Tanzania grass ${ }^{(1)}$.

\begin{tabular}{|c|c|c|c|c|c|c|c|}
\hline \multirow{2}{*}{$\begin{array}{c}\text { Grazing } \\
\text { intervals (days) }\end{array}$} & \multicolumn{7}{|c|}{ Evaluation period } \\
\hline & $\begin{array}{l}\text { October/ } \\
\text { December }\end{array}$ & $\begin{array}{l}\text { January/ } \\
\text { February }\end{array}$ & $\begin{array}{c}\text { February/ } \\
\text { April }\end{array}$ & $\begin{array}{l}\text { April/ } \\
\text { May }\end{array}$ & $\begin{array}{l}\text { May/ } \\
\text { July }\end{array}$ & $\begin{array}{c}\text { July/ } \\
\text { August }\end{array}$ & $\begin{array}{c}\text { August/ } \\
\text { September }\end{array}$ \\
\hline & & & & Stem length & & & \\
\hline 28 & $18.6 \mathrm{Bd}$ & $29.4 \mathrm{Cc}$ & $36.3 \mathrm{Bb}$ & $47.9 \mathrm{Ca}$ & $24.1 \mathrm{Bc}$ & 15.2Ade & 14.9Be \\
\hline 38 & $21.7 \mathrm{Bd}$ & $44.4 \mathrm{Bc}$ & $37.9 \mathrm{Bb}$ & $60.0 \mathrm{Ba}$ & $27.7 \mathrm{ABc}$ & $14.5 \mathrm{Ae}$ & $16.1 \mathrm{ABe}$ \\
\hline 48 & $29.0 \mathrm{Ac}$ & $59.9 \mathrm{Ab}$ & $50.5 \mathrm{Ab}$ & 148.6Aa & $31.8 \mathrm{Ac}$ & 16.9Ad & 19.6Ad \\
\hline
\end{tabular}

${ }^{(1)}$ Means followed by the same lower case letter in a row or the same upper case letter in a column do not differ significantly by the LSD test $(\mathrm{P}<0.05)$; pasture was grazed by Holstein cows and heifers. 
be observed although there may be a reduction on grazing efficiency. This is important for situations in which the control over grazing intervals is precarious.

\section{Conclusions}

1. Tanzania grass grazing intervals should be around 38 days from October until April (late spring, summer and early autumn), around 28 days during the reproductive phase (April/May) and more than 48 days between May and September (late autumn and winter).

2. Herbage accumulation rate is not a good criterion to establish a defoliation schedule for Tanzania grass; stems development should also be considered to determine Tanzania grass grazing intervals.

\section{References}

ANDRADE, J. B. Estudo comparativo de três capins da espécie Panicum maximum Jacq. (colonião, tobiatã e K-187-B). 1987. 133 f. Dissertação (Mestrado em Agronomia) - Escola Superior de Agricultura Luiz de Queiroz, Piracicaba, 1987.

BAKER, A. M.; YOUNGER, A. Factors affecting the leaf extension rate of perennial ryegrass in spring. Grass and Forage Science, Oxford, v. 42, p. 381-390, 1987.

BARBOSA, R. A.; NASCIMENTO JÚNIOR, D.; EUCLIDES, V. P. B.; REGAZZI, A. J.; FONSECA, D. M. Características morfogenéticas e acúmulo de forragem do capim-tanzânia (Panicum maximum Jacq. cv. Tanzânia) em dois resíduos forrageiros pós-pastejo. Revista Brasileira de Zootecnia, Viçosa, MG, v. 31, p. 583-593, 2002.

BARTHRAM, G. T.; GRANT, S. A. Defoliation of ryegrass-dominated swards by sheep. Grass and Forage Science, Oxford, v. 39, p. 211-219, 1984.

CORRÊA, L. A. Produção de carne em pastagens adubadas. São Carlos: Embrapa-CPPSE, 2000. 25 p. (Circular Técnica, 25).

COSTA, C.; FAVORETTO, V.; MALHEIROS, E. B. Estudo da variação na estrutura da vegetação de duas cultivares de Panicum maximum Jacq. (Colonião e Tobiatã) submetidas a diferentes tipos de manejo. 1. Produção e densidade de perfilhos e de matéria seca. Pesquisa Agropecuária Brasileira, Brasília, v. 27, n. 1, p. 131-142, jan. 1992.

Pesq. agropec. bras., Brasília, v. 38, n. 8, p. 991-997, ago. 2003
EUCLIDES, V. P. B.; THIAGO, L. R. L. S.; MACEDO, M. C. M.; OLIVEIRA, M. P. Consumo voluntário de forragem de três cultivares de Panicum maximum sob pastejo. Revista Brasileira de Zootecnia, Viçosa, MG, v. 28, p. 1177-1185, 1999.

FERRARIS, R. The effect of photoperiod and temperature on the first crop and ratoon growth of Pennisetum purpureum (Schum.). Australian Journal of Agricultural Research, Collingwood, v. 29, p. 941-950, 1978.

FLORES, E. R.; LACA, E. A.; GRIGGS, T. C.; DEMMENT, M. W. Sward height and vertical morphological differentiation determine cattle bite dimensions. Agronomy Journal, Madison, v. 85, p. 527-532, 1993.

FORBES, T. D. A.; COLEMAN, S. W. Forage intake and ingestive behavior of cattle grazing old world bluestems. Agronomy Journal, Madison, v. 85, p. 808-816, 1993.

GRANT, S. A.; BARTHRAM, G. T.; TORVELL, L.; KING, J.; SMITH, H. K. Sward management, lamina turnover and tiller population density in continuously stocked Lolium perenne-dominated swards. Grass and Forage Science, Oxford, v. 38, p. 333-344, 1983.

HODGSON, J. Grazing management: science into practice. New York: Longman Scientific \& Technical, 1990. $203 \mathrm{p}$.

HOPKINS, W. G. Introduction to plant physiology. New York: J. Wiley, 1995. 464 p.

JANK, L.; SAVIDAN, Y.; SOUZA, M. T.; COSTA, J. G. C. Avaliação do germoplasma de Panicum maximum introduzido da África. 1. Produção forrageira. Revista da Sociedade Brasileira de Zootecnia, Viçosa, MG, v. 23, p. 433-440, 1994.

KING, J.; GRANT, S. A.; TORVELL, L.; SIM, E. M. Growth rate, senescence and photosynthesis of ryegrass swards cut to maintain a range of values for leaf area index. Grass and Forage Science, Oxford, v. 39, p. 371-380, 1984.

NOODËN, L. D.; HILLSBERG, W.; SCHNEIDER, M. J. Induction of leaf senescence in Arabidopsis thaliana by long days through a light-dosage effect. Physiologia Plantarum, Copenhagen, v. 96, p. 491-495, 1996.

PARSONS, A. J.; PENNING, P. D. The effect of duration of regrowth on photosynthesis, leaf death and the average rate of growth in a rotationally grazed sward. Grass and Forage Science, Oxford, v. 43, p. 15-27, 1988. 
PENATI, M. A. Estudo do desempenho animal e produção do capim-tanzânia (Panicum maximum, Jacq.) em um sistema rotacionado de pastejo sob irrigação em três níveis de resíduo pós-pastejo. 2002. $117 \mathrm{f}$. Tese (Doutorado em Agronomia) - Escola Superior de Agricultura Luiz de Queiroz, Piracicaba, 2002.

POPPI, D. P.; MINSON, D. J.; TERNOUTH, J. H. Studies of cattle and sheep eating leaf and stem fractions of grasses: I. The voluntary intake, digestibility and retention time in the reticulo-rumen. Australian Journal of Agricultural Research, Collingwood, v. 32, p. 99-108, 1981.

QUADROS, D. G.; RODRIGUES, L. R. A.; FAVORETTO, V.; MALHEIROS, E. B.; HERLING, V. R.; RAMOS, A. K. B. Componentes da produção de forragem em pastagens dos capins Tanzânia e Mombaça adubadas com quatro doses de NPK. Revista Brasileira de Zootecnia, Viçosa, MG, v. 31, p. 1333-1342, 2002.

SANTOS, P. M. Estudo de algumas características agronômicas de Panicum maximum (Jacq.) cvs. Tanzânia e Mombaça para estabelecer seu manejo.
1997. 62 f. Dissertação (Mestrado em Agronomia) - Escola Superior de Agricultura Luiz de Queiroz, Piracicaba, 1997.

SANTOS, P. M.; CORSI, M.; BALSALOBRE, M. A. A Efeito da frequiência de pastejo e da época do ano sobre a produção e a qualidade em Panicum maximum cvs. Tanzânia e Mombaça. Revista Brasileira de Zootecnia, Viçosa, MG, v. 28, p. 244-249, 1999.

SAS INSTITUTE (Cary, United States). SAS user's guide: statistics. Cary, 1986. 419 p.

SINGH, D. K. Effects of cutting management on yield and quality of different selections of guinea grass (Panicum maximum, Jacq.) in a humid subtropical environment. Tropical Agriculture, London, v. 72, p. 181-187, 1995.

SOLLENBERGER, L. E.; BURNS, J. C. Canopy characteristics, ingestive behaviour and herbage intake in cultivated tropical grasslands. In: INTERNATIONAL GRASSLAND CONGRESS, 19., 2001, São Pedro. Proceedings... Piracicaba: Fealq, 2001. p. 321-327.

WOLEDGE, J. The effect of shading on the photosynthetic rate and longevity of grass leaves. Annals of Botany, London, v. 36, p. 551-561, 1972. 